\title{
An investigation on mate preferences with emphasize on the role of personality characters
}

\author{
Fatemeh Sadat Dibaj $^{\mathrm{a}}$, Ozra Etemadi ${ }^{\mathrm{b} *}$, Fateme Bahramic ${ }^{\mathrm{c}}$, Mohammadreza Abedi ${ }^{\mathrm{d}}$ and Maryamsadat \\ Fatehizade $^{\mathrm{d}}$
}

${ }^{a}$ Student of PhD in Family Counseling, School of Educational Science and Psychology, University of Isfahan, Iran

${ }^{b}$ Assistant Professor in Counseling Department, University of Isfahan, Iran

'full Professor in Counseling Department, University of Isfahan, Iran

${ }^{d}$ Associate Professor in Counseling Department, University of Isfahan, Iran

\section{H R O N I C L E}

\section{Article history:}

Received June 28, 2013

Received in revised format

19 October 2013

Accepted 20 December 2013

Available online

December 312013

\section{Keywords:}

Big five personality

Mate preferences

Iranian culture

\begin{abstract}
A B S T R A C T
This study investigated the relationships between Big-Five personality traits and mate preferences in Isfahan, Iran. The sample consisted of 225 single girls and boys that they were volunteer to complete the research measures. They completed of Neo- FFI-3 to evaluate personality traits and Iranian cultural preference questionnaire. To response to research question, data was examined in two steps. The first step was to examine the intercorrelate relations matrix among dependent and independent variables. The results showed extraversion is related to attractive appearance, educational level, no having sexy relations with opposite sex in single period, and no having addiction. Also attractive appearance and no having too close relations with each other family is correlated with neuroticism and conscientiousness. Also extraversion can predict attractive appearance and no having addiction preferences. Neuroticism can predict no having too close relations with mate families preference. Other variables, although contributing to the overall variance, were not significant predictors in our focused and cultural preferences.
\end{abstract}

\section{Introduction}

Human mating is the process whereby an individual seeks out another individual with the intention of forming to a long-term intimate relationship or marriage, but sometimes for casual relationship or friendship. The human desire for companionship is one of the strongest human drives. The mating process encompasses the social and cultural processes where by one person may meet another to assess suitability, the courtship process and the process of forming an interpersonal relationship. Mate preferences in humans are associated with understanding on why one human chooses or chooses not to mate with another human and their reasoning why. The most documented theory of human mating 
is that likes attract likes that men and women become coupled with those who are similar to themselves (Buss, 1989; Thissen \& Gregg, 1980).

A preliminary review of literatures shows different human mate selection perspectives that psychologists have examined, such as the selection strategies that people have developed to evaluate potential mates (Eagly \& wood, 1999; Feingold, 1992) and the criteria that men and women seek in a mate (e.g., Howard et al., 1987; Schmitt et al., 2001, Li et al., 2010). Confer et al. (2010) studied short vs. Long - term mating strategies. Change et al. (2011) studied the role of cultural evolution. The role of parent was examined too (Periloux et al., 2011). However many researchers have studied different factors (e.g., Haselton et al., 2005; Shackelford et al., 2005) and, in Iran, few studies have investigated human mating preferences. Rajabi et al. (2011) showed religion, behavior characters and social skills are important in mating among Iranian.

In this paper, we investigate multiple relationships among big five personality factors with mate preferences (physical attractiveness, physical health, education, economical status, no having sex with opposite sex in single time, no having close relationships with family in law, no having history of delinquency and violation, mutual family agreeable to their marriage). This research provides the first empirical tests of whether personality traits play important role in mate preferences. Some studied preferences are cultural variables and particularly belong to Iranian culture (such as no having sex relationships with opposite sex in single period or mutual family agreeable to their marriage). The following shows the goal of the research:

Determination of multiple relations among big five personality with mate preferences

\section{Big five personality factors}

The big five personality factors model (MaCare \& Costa, 1997) represents the dominant conceptualization of personality structure. This model is included five relatively independent dimensions including Neuroticism, Extraversion, openness to experiences, Agreeableness and Conscientiousness reside at the highest level of the personality hierarchy. Extraversion reflects tendencies associated with being assertive, talkative, and sociable (Barrick \& Mount, 1991). Neuroticism reflects the tendency to experience distress (McCare \& John, 1992). It includes being anxious, depressed, emotional, worried and insecure (Barric, \& Mount, 1991). Openness to experience is associated with be scientific and artistic creativity, divergent thinking and political liberalism (Judge et al., 2002). The behavioral tendencies typically associated with it include being imaginative cultured, intelligent and artistically sensitive. Agreeableness is the fourth factor, which describes tendencies typically associated with this factor includes good - natured, courteous, cooperative and tolerant. The final factor is conscientiousness. The typical behaviors associated with conscientiousness comprise being hard working, achievement - oriented, and preserving (Barrack \& Mount, 1991). We investigated whether big five personality traits have correlated with mate preferences.

\section{Method}

\subsection{Sample Selection}

The data for this cross - sectional study came from the statistical population of all youth in Isfahan over the period 2011-2012. The sample comprised 225 single girls and boys who were volunteers to complete the research measures. They completed of Neo- FFI-3 to evaluate personality traits and Iranian cultural preference questionnaire. The mean age was 22.5 and standard deviations of 4.21.

\subsection{Measurement Instruments}

Big-Five personality traits questionnaire. In this study short form of Big-Five personality traits were used (McCrea \& Costa, 1992). This questionnaire has 60 items. Participants were asked to indicate 
their response to each item on a five point Likert scale ranging from strongly disagree (1) to strongly agree (5). Higher scores indicated higher levels of each dimension. Costa and McCrae reported internal consistency coefficient alphas ranging from 0.68 to 0.86 and provide extensive validity data. In the present study, internal consistency was assessed. Cronbach's alpha for the present sample were 0.58 (Neuroticism), 0.73 (Extraversion), 0.60 (Openness to Experience), (Agreeableness) 0.54 and (Conscientiousness) 0.82.

\subsection{Preferences questionnaire}

We used a questionnaire that it included, Iranian cultured items (e.g. Mutual family agreeable to their marriage and general items (e.g. beautiful appearance). Participants respond to items by endorsing their degree of their agreement with every preferences on a 5- point , like - type scale ranging from 1 (strongly disagree) to 4 (strongly agree). Its internal consistency calculated by Cranach Alpha. It was acceptable (as .85) Table 1 shows items of this questionnaire.

\section{Table 1}

Items of mate preference ratings

1. Beautiful appearance

2. Physical Heath

3. Educational status

4. Economic status

5. No having sexy relationships with opposite sex in his / her single period.

6. No having too close relations or dependency with her/his families.

7. No having history of delinquency and misdoing.

8. No having addiction

9. Mutual family agreeable to their marriage Results

\section{Result}

To response to research questions, data was examined in two steps. The first step was to examine the intercorrelate relations matrix among dependent and independent variables summarized in Table 3. The results showed attractive appearance was significantly and positively associated with extraversion $(r=.264, \mathrm{p}<.05)$ meaningfully and negatively with neuroticism $(r=-.203, \mathrm{p}<.05)$.

Educational level was significantly and positively associated with extraversion $(\mathrm{r}=.236, \mathrm{p}<.05)$ and significantly and negatively associated with psychosis $(\mathrm{r}=-.310, \mathrm{p}<.05)$. No having sexy relations with opposite sex in single periods was associated significantly with extraversion $(r=.237, p<.95)$. No having too close relationships with each other families was related significantly and negatively with neuroticism $(\mathrm{r}=-.278, \mathrm{p}<.05)$ and significantly and positively with conscientiousness $(\mathrm{r}=.272$, $\mathrm{P}<.05)$. No having addiction was significantly and meaningfully with extraversion $(\mathrm{r}=.224, \mathrm{p}<.05)$ other variable had no meaningful correlations.

\subsection{Predicting Mate Preferences}

Multiple regression analysis was conducted to response research questions in relation to predicting mate preferences. Beautiful appearance was entered as the dependent variable and big five factors were entered as the independent variables. Summary data were presented in Table 4. The results indicated a significant model fit, $\mathrm{F}=5.12 \mathrm{p}=.028$ and that the independent variable (extraversion) included in the model was able to account for 8.7 of the variance $\left(\mathrm{R}^{2}=.087\right)$. No having too close relationships with couple families were entered as dependent variable and big factors were entered as independent variables. 
The results indicated a significant model fit, $\mathrm{F}=4.52, \mathrm{P}=.038$ and that the independent variable neuroticism included in the model was able to account for $7.7 \%$ of the variance $\left(\mathrm{R}^{2}=.077\right)$. No having addiction was entered as dependent variable and big five factors were entered as independent variables. The results showed a significant model fit, $\mathrm{F}=5.12, \mathrm{p}=.028$ and that the independent variable (extraversion) included in the model was to account for $8.7 \%$ of the variance $\left(\mathrm{R}^{2}=.087\right.$ )

Table 2

Means and standard Deviations for dependent and independent variables

\begin{tabular}{llll}
\hline Variables & Mean & Sd & N \\
\hline 1 & 3.34 & 2.23 & 225 \\
\hline 2 & 4.64 & 2.28 & 225 \\
\hline 3 & 3.55 & 2.54 & 225 \\
\hline 4 & 3.04 & 2.59 & 225 \\
\hline 5 & 4.18 & 2.84 & 225 \\
\hline 6 & 3.88 & 2.65 & 225 \\
7 & 4.54 & 2.34 & 225 \\
\hline 8 & 4.62 & 2.26 & 225 \\
\hline 9 & 4.25 & 2.62 & 225 \\
\hline 10 & 32.86 & 6.79 & 225 \\
\hline 11 & 39.84 & 5.67 & 225 \\
\hline 12 & 41.60 & 5.52 & 225 \\
13 & 43.09 & 5.13 & 225 \\
\hline 14 & 43.98 & 5.53 & 225 \\
\hline 1. Attractive appearance & & 8. No having addiction & \\
2. Physical Health & & 9. Mutual families agreeable to the their marriage \\
3. Educational level & 10. Neuroticism & \\
4. Economic status & 12. Oxtraversion & \\
5. No having sex relationships with opposite sex in single periods. & 13. Agreeableness & \\
6. Having zoo close relationships with each other families. & 14. Conscientiousness & \\
7. No having history of delinquency and misdoing. & & & \\
\hline
\end{tabular}

Table 3

Pearson correlations among dependent and independent variables

\begin{tabular}{|c|c|c|c|c|c|c|c|c|c|}
\hline Variables & 1 & 2 & 3 & 4 & 5 & 6 & 7 & 8 & 9 \\
\hline Psychosis & $-.243^{\prime}$ & -.044 & $-.310^{\prime \prime}$ & .008 & .000 & $-.278^{\prime}$ & .029 & .035 & .124 \\
\hline Extraversion & $.264^{\prime}$ & .211 & $.236^{\prime}$ & -.064 & $.234^{\prime}$ & .123 & .175 & $.294^{\prime}$ & .000 \\
\hline Openness to experience & -.011 & -090 & -.037 & .193 & -.025 & .097 & .166 & $240^{\prime}$ & .082 \\
\hline Agreeableness & -.027 & .041 & .982 & -013 & .031 & .036 & .159 & .095 & .198 \\
\hline Conscientiousness & .048 & .213 & .339” & .102 & .167 & $.272^{\prime}$ & .140 & .027 & .183 \\
\hline
\end{tabular}

Note: $"=\mathrm{p}<0.01 \quad ‘=\mathrm{p}<0.05$

\section{Table 4}

Stepwise multiple regressions of mate preferences based on personality characters

\begin{tabular}{llllllll}
\hline Dependent variable & Model & Variables & B & SEB & P & T & Sig. \\
\hline 1 & 1 & Extraversion & .031 & .015 & .264 & 2.008 & .005 \\
6 & 1 & Neuroticism & -034 & .016 & -.278 & -2012 & .038 \\
8 & 1 & Extraversion & .032 & .04 & .294 & 2.26 & .082 \\
\hline
\end{tabular}

\section{Discussion}

About 90\% of all people in all societies marry at some point in their lives (Buss, 1985; Vandenberg, 1972). Many researches have investigated the characteristics that men and women prefer in a longterm relationships (e.g. Okami \& Shackelford, 2001; Buss, 2003). We wanted to know whether big five personality traits have any role in mate preferences. Although some research has examined personality mate preferences (e.g. Botwin et al., 1997; Lokaszewski \& Roney, 2009; Norman et al., 2011), the role of personality traits has not been in focus of research attention. 
Our results showed extraversion is related to attractive appearance, educational level, no having sexy relations with opposite sex in single period, and no having addiction. Also attractive appearance and no having too close relations with each other family is correlated with neuroticism and conscientiousness. In addition, extraversion can predict attractive appearance and no having addiction preferences. Neuroticism can predict no having too close relations with mate families preference. Other variables, although contributing to the overall variance, were not significant predictors in our focused and cultural preferences.

How we can explain these finding? It seems that extroverted individuals have some which traits such as being assertive, talkative and sociable (Barrik., \& Mount, 1991) which cause they prefer some especial mate preferences (attractive appearance and no having addiction). Perhaps, their repeated social experiences cause they pay attention to pointed preferences.

As pointed In Iranian culture wife's and husband's family or family in law play important role in marital satisfaction. There for many girls and boys, the types of their relations with their family in law are important. Neuroticism can predict having too close relations with each other family preference. Neuroticism points to the tendency to experience distress (Costa., \& McCrae, 1995). It includes being anxious, depressed, emotional and insecure (Barrick \& Mount, 1991). It seem neurotic individuals need additional support from their families and families in law.

Therefore, negative correlation between neuroticism and no having too close relations with each other family preference is not surprisingly.

The person correlation results show conscientiousness is correlated positively with no having too close relations with each other family preference. The trait included sub traits such as being achievement - oriented and hard - waking (Barrick \& Mount, 1991). It seems the pointed sub traits because the individuals need more time for themselves. Therefore they avoid from family enmeshment.

In summery, it seems that beside universal mate preferences, Iranian culture has included some especial mate preferences. We open new window in culture specific mate preferences. In the other hand, we paid to the factors that they could have role in mate preferences. These findings may present an important basic contribution to the mate preferences via its attention to underling factors in mate preferences.

Study limitations: The results of this study were limited by self - report nature of the instruments and its sampling. Results based upon a small sample for one area of Iran. All the participants were Muslim even though there are Christians and other minority religions in Iran. Hoverer, we suggest that future research examines other correlated variables with mate preference which may be determining in variance of mating.

\section{References}

Barrick, M. R. \& Mount, M. K. (1991). The big five personality dimensions and job performance: A meta-analysis. Personnel Psychology, 44, 1 - 26.

Botwin, M., Buss, D. M., \& Shackelford, T. K. (1997). Personality and mate preferences: Five factors in mate selection and marital satisfaction. Journal of Personality, 65, 107-136.

Buss, D. (2007). The evolution of human mating. Acta Psychologica Sinica, 39, 502-512.

Buss, D. M. (1985). Human mate selection. American Scientist, 73, 47-51.

Buss, D. M. (1989). Sex differences in human mate preferences: Evolutionary hypotheses tested in 37 cultures. Behavioral and Brain Sciences, 12, 1-49.

Buss, D.M. (2003). Sexual strategies: A journey into controversy. Psychological Inquiry, 14, 217224. 
Chang, L., Wang, Y., Shackelford, T. K., \& Buss, D. M. (2011). Chinese mate preferences: Cultural evolution and continuity across a quarter of a century. Personality and Individual Differences, 50(5), 678-683.

Confer, J. C., Perilloux, C., \& Buss, D. M. (2010). More than just a pretty face: Men's priority shifts toward bodily attractiveness in short-term versus long-term mating contexts, Evolution and Human Behavior, 31(5), 348-353.

Costa, P. T., \& McCrae, R. R. (1992). Neo PI-R professional manual. Odessa, FL: Psychological.

Costa, P. T., \& McCrae, R. R. (1995). Domains and facets: Hierarchical personality assessment using the Revised NEO Personality Inventory. Journal of Personality Assessment, 64, 21-50.

Eagly, A. H., \& Wood, W. (1999). The origins of sex differences in human behavior: Evolved dispositions versus social roles. American Psychologist, 54, 408-423.

Feingold, A. (1992). Gender differences in mate selection preferences: a test of the parental investment model. Psychological Bulletin, 112(1), 125-39.

Haselton, M., Buss, D.M., Oubaid, V., \& Angleitner, A. (2005). Sex, lies, and strategic interference: The psychology of deception between the sexes. Personality and Social Psychology Bulletin, 31(1), 3-23.

Howard, J.A., Blumstein, P., Schwartz, P. (1987). Social or evolutionary theories. Some observations on preferences in human mate selection. Journal of Personality and Social Psychology, 53(1), 194-200.

Judge, T. A., D, Heller, \& and Mount, M. K. (2002). Five-factor model of personality and job satisfaction: A meta-analysis. Journal of Applied Psychology, 87(3), 530-541.

Li, N. P., Valentine, K. A., \& Patel, L. (2011). Mate preferences in the U.S. and Singapore: A crosscultural test of the mate preference priority model. Personality and Individual Differences, 50, 291-294.

McCrae, R.R., \& Costa, P.T. (1997) Personality trait structure as a human universal. American Psychologist, 52, 509-516.

McCrae, R.R., \& John, O.P. (1992). An introduction to the five-factor model and its applications. Journal of Personality, 60 (2), 175-215.

Okami, P., \& Shackelford, T. K. (2001). Human sex differences in sexual psychology and behavior. Annual Review of Sex Research, 12, 186-241.

Perilloux, C., Fleischman, D. S., \& Buss, D. M. (2011). Meet the parents: Parent-offspring convergence and divergence in mate preferences. Personality and Individual Differences, 50, 253258.

Rajabi, G., Ebrahimi, M., \& Khojastemehr R. (2011). Comparison and Ranking of Mate-Selection Preferences between Female and Male and students Kord, Arabian, and Bakhtiyari Ethnic Groups Shahid Chamran of University, 2 (4), 61-67

Schmitt, D. P., Shackelford, T. K., Duntley, J., Tooke, W., \& Buss, D. M. (2001). The desire for sexual variety as a key to understanding basic human mating strategies. Personal Relationships, 8(4), 425-455.

Shackelford, T. K., Schmitt, D. P., \& Buss, D. M. (2005). Mate preferences of married persons in the newlywed year and three years later. Cognition and Emotion, 19, 1262-1270.

Thiessen, D., \& Gregg, B. (1980). Human assortative mating and genetic equilibrium: An evolutionary perspective. Ethology and Sociobiology, 1(2), 111-140. 